\title{
Pojazdowe zasobniki energii dla trakcji kolejowej
}

\begin{abstract}
W artykule przedstawiono aktualny stan rozwoju i zastosowań zasobników energii elektrycznej. Szeroki krag odbiorców (energetyka odnawialna, odbiorcy komunalni, transport) sprawia, że zasobniki energii $w$ sposób znaczqcy wplywaja na system elektroenergetyczny poprzez oszczędności energii oraz poprawe jej jakości. Nowoczesnym elementem zasobników energii elektrycznej sq superkondensatory, które cechujq sie dużymi pojemnościami i gęstościami mocy. Pojazdowe zasobniki energii, poprzez zwiększenie efektywności odzysku energii w trakcie hamowania elektrodynamicznego, umożliwiaja lepsza prace systemów rekuperacyjnych $w$ trakcji kolejowej. Zostata przedstawiona analiza aplikacji superkondensatorów do zasobników energii, na przykładzie tramwaju $116 \mathrm{~N}$.
\end{abstract}

\section{Przegląd zasobników energii}

Zasobniki energii elektrycznej pełnią kilka podstawowych funkcji. Dla systemów energetyki odnawialnej, w których ilość wytwarzanej energii zależy od warunków pogodowych (słońce, wiatr) pozwalają one zmagazynować energię, która nie może być $\mathrm{w}$ danej chwili wykorzystana przez odbiorców. System magazynowania energii, pozwala również uniknąć sytuacji, w których nagłe zmiany parametrów źródła zasilającego powodują zakłócenia w systemie elektroenergetycznym. Wykorzystanie zasobników pozwala na poprawę jakości napięcia zasilającego. Systemy zasobnikowe są szeroko stosowane w większości elektrowni wiatrowych, a jeden z największych znajduje się na wyspie Big Island [1].

Dla odbiorców komunalnych zasobnik energii pozwala na zgromadzenie energii $\mathrm{w}$ nocnych lub wczesnych godzinach popołudniowych, a następnie wykorzystanie jej podczas dobowych szczytów zapotrzebowania energetycznego. Teoretycznie, dzięki temu, użytkownik posiadający zasobnik energii, stałby się dla systemu energetycznego odbiorcą o obciążeniu stałym i zapotrzebowaniu na moc równą $\mathrm{P}_{\text {śr. }}$ W przypadku rozliczeń dwutaryfowych, energia do zasobników będzie pobierana wtedy, gdy jest najtańsza a zużywana może być w dogodnym dla użytkownika czasie. Dla zakładów energetycznych może być to sytuacja trudna. $Z$ jednej strony sprzedadzą więcej tańszej energii, a mniej droższej, co $\mathrm{w}$ sumie prowadzi do mniejszych dochodów. Z drugiej jednak strony, dobowe wyrównanie zapotrzebowania na moc, pozwoliłoby uniknąć w elektrowniach uruchamiania dodatkowych bloków podczas dobowych szczytów, wyrównania trybu jej pracy, co w konsekwencji prowadzi do zmniejszenia kosztów produkcji energii.
Zasobniki energii pełnią także bardzo ważną funkcję w transporcie, zarówno samochodowym jak i kolejowym. Najnowsze modele samochodów posiadają napędy hybrydowe: spalinowo-elektryczne. Współpraca silnika spalinowego i elektrycznego oraz odzysk części energii hamowania pozwala na zdecydowane zmniejszenie spalania. Dla użytkownika samochodu hybrydowego, to oczywiście oszczędności finansowe. Patrząc jednak globalnie, zmniejszenie spalania to mniejsze zużycie tlenu, mniejsza emisja $\mathrm{CO}_{2}$ oraz innych gazów będących skutkiem spalania paliwa. Można zatem powiedzieć, że samochód hybrydowy to samochód proekologiczny.

Dzięki wykorzystaniu hamowania elektrodynamicznego w pojazdach elektrycznych stało się możliwe odzyskanie części energii wykorzystanej do rozruchu i jazdy pojazdu. Oczywiście w pojazdach nie wykorzystuje się jedynie tego sposobu hamowania. Mając świadomość występujących strat mechanicznych, cieplnych można przyjąć, że poprzez odpowiednie układy nergoelektroniczne, możliwy jest odzysk energii na poziomie $20-30 \%$ energii pobranej przez układ napędowy $[3,5]$. Zależy to od rodzaju pojazdu (tramwaj, metro, trolejbus), charakterystyki trasy po której się porusza oraz zastosowanego systemu odzyskiwania energii. Energia, która jest oddawana podczas hamowania może być odebrana przez inny pojazd, który znajduje się na danym odcinkui potrzebuje energii lub zmagazynowana $\mathrm{w}$ zasobniku. Ponieważ nie zawsze pierwsza sytuacja może mieć miejsce, najbezpieczniej jest wyposażyć system rekuperacji w zasobniki energii. 
2. Superkondensator jako element nowoczesnego zasobnika energii

Podstawowym elementem nowoczesnego zasobnika energii jest bateria superkondensatorów. Dla lepszego scharakteryzowania ich właściwości i potencjalnych możliwości poglądowo opisano ich budowę i sposób działania. Typowe kondensatory zbudowane są $\mathrm{z}$ dwóch elektrod oraz znajdującego się między nimi dielektryka. Pojemność (1) tak zbudowanego kondensatora płaskiego jest wprost proporcjonalna do przenikalności elektrycznej danego dielektryka i powierzchni okładek oraz odwrotnie proporcjonalna do odległości między okładkami.

$$
C=\varepsilon_{0} \varepsilon_{r} \frac{S}{d}
$$

gdzie: C - pojemność kondensatora płaskiego, $\mathrm{S}-$ powierzchnia okładek kondensatora, d - odległość między okładkami, $\varepsilon_{0}$ - przenikalność elektryczna próżni, $\varepsilon_{\mathrm{r}}-$ względna przenikalność elektryczna dielektryka.

Tak zbudowane kondensatory mają pojemności rzędu nano-, mikro- lub milifaradów.

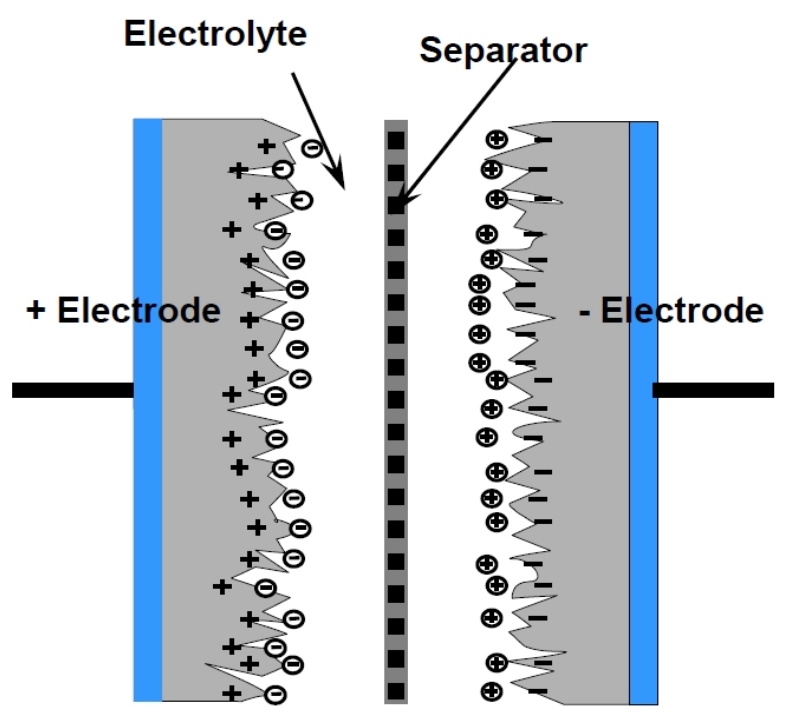

Rys. 1. Model budowy superkondensatora [7]

Na rys. 1 został przedstawiony model budowy superkondensatora. Jego elektrody pokryte są węglem aktywnym, który charakteryzuje się bardzo dużą powierzchnią na jednostkę masy $\left(\sim 2000 \mathrm{~m}^{2} / \mathrm{g}\right)$. Dzięki temu powierzchnia okładek jest duża, co zgodnie z (1) powoduje wzrost pojemności superkondensatora. Drugą istotną różnicą pomiędzy standardowym kondensatorem, a superkondensatorem jest to, że w tych drugich nie ma dielektryka. Pomiędzy elektrodami znajduje się elektrolit, który jest przewodnikiem prądu. Pod wpływem przyłożonego napięcia jony dodatnie zbliżają się do elektrody ujemnej, a jony ujemne to elektrody dodatniej. Poniżej pewnego napięcia, określonego przez rodzaj elektrolitu, jony z elektrodą tworzą tzw. podwójną warstwę elektryczną, którą po raz pierwszy zamodelował Helmholtz [6]. Bardzo mała grubość tej warstwy powoduje, że odległość $d$ z (1) jest bliska zeru, co prowadzi do zwiększenia pojemności superkondensatora. Separator znajdujący się pomiędzy elektrodami stanowi zabezpieczenie przed bezpośrednim zwarciem elektrod. Dla jonów separator nie stanowi izolacji.

Wspomniana technologia superkondensatorów pozwala na uzyskiwanie pojemności rzędu setek i tysięcy faradów. Firma Maxwell Technologies, zajmująca się produkcją superkondensatorów na skalę przemysłową, ma w swojej ofercie wiele pojedynczych superkondensatorów oraz gotowe moduły. Np. superkondensator o pojemności $3 \mathrm{kF}$ ma wymiary walca o długości $168 \mathrm{~mm}$, średnicy $60 \mathrm{~mm}$ i waży $0,55 \mathrm{~kg}$. Bardzo krótki czas ładowania i rozładowania pozwala osiagać gęstość mocy do $\mathrm{P}_{\max }=13,8 \mathrm{~kW} / \mathrm{kg}$, przy gęstości energii $\mathrm{E}_{\max }=5,52 \mathrm{Wh} / \mathrm{kg}$ [7].

Ze względu na niską wartość napięcia znamionowego $\left(\mathrm{U}_{\mathrm{N}}=2,7 \mathrm{~V}\right)$, energia zgromadzona (2) w jednym superkondensatorze nie jest duża.

$$
E_{\max }=\frac{1}{2} C U^{2}
$$

gdzie: $\mathrm{E}_{\max }-$ maksymalna energia zgromadzona $\mathrm{w}$ superkondensatorze, $\mathrm{C}$ - pojemność superkondensato$\mathrm{ra}, \mathrm{U}$ - napięcie znamionowe superkondensatora

W związku z tym łączy się je w zespoły szeregowe i szeregowo-równoległe. Jest to jednak skomplikowany proces, ponieważ istotne jest, aby napięcie na każdym z nich nie przekroczyło dopuszczalnej wartości. W tym celu wykorzystuje się pasywne, bądź aktywne układy wyrównywania napięć, których tematyka ze względu na ograniczone miejsce w niniejszym referacie nie będzie poruszona.

\section{Trakcyjne zasobniki energii}

W trakcji kolejowej wyróżnia się dwa podstawowe rodzaje zasobników energii elektrycznej: podstacyjne oraz pojazdowe. Jak wskazują nazwy pierwsze $\mathrm{z}$ nich znajdują się na podstacjach, a drugie na pojazdach.

Przykładem zasobnika podstacyjnego jest Sitras SES (Stationary energy storage system for DC traction Power supply) firmy SIEMENS [8] zbudowany w całości na bazie superkondensatorów. Zasobnik oferowany jest $\mathrm{w}$ dwóch modelach, a ich dane techniczne zostały zestawione w tabeli 1. Zasobnik Stras SES posiada dwa tryby pracy. Pierwszy jako stabilizator napięcia, wtedy ilość energii w nim zgromadzona jest utrzymywana ciagle na wysokim poziomie i wykorzystywana jest, kiedy napięcie w trakcji spadnie poniżej granicznej wartości. Drugi rodzaj pracy, jako magazyn energii, którą oddają pojazdy podczas hamowania. Według producenta system sterowania potrafi automatycznie dostosować się do warunków pracy i przełączyć na odpowiedni tryb. Podstawową wadą zasobników podstacyjnych jest ich odległość od pojazdów, co 
Tabela 1. Dane techniczne zasobnika Sitras SES [8]

\begin{tabular}{|l|c|c|c|}
\hline $\begin{array}{l}\text { Napięcie wejściowe DC (tolerancja zgodna z EN } \\
50163 \text { ) }\end{array}$ & {$[\mathrm{V}]$} & 600 & 750 \\
\hline Całkowita liczba superkondensatorów & & 1050 & 1344 \\
\hline Całkowita pojemność & {$[\mathrm{F}]$} & 103 & 80 \\
\hline Pojemność energetyczna & {$[\mathrm{kWh}]$} & 1,7 & 2,5 \\
\hline Maksymalna oszczędność energii na godzinę & {$[\mathrm{kWh} / \mathrm{h}]$} & 50 & 80 \\
\hline Moc szczytowa & {$[\mathrm{MW}]$} & 1 & 1 \\
\hline $\begin{array}{l}\text { Napięcie zasilania urządzeń pomocniczych AC } \\
\text { 50Hz }\end{array}$ & {$[\mathrm{V}]$} & $3 \times 400$ & $3 \times 400$ \\
\hline Dopuszczalna temperatura otoczenia & {$\left[{ }^{\circ} \mathrm{C}\right]$} & $-20 \ldots+40$ & $-20 \ldots+40$ \\
\hline Wysokość pracy nad poziomem morza & {$[\mathrm{m}]$} & $? 2000$ & $? 2000$ \\
\hline $\begin{array}{l}\text { Wymiary czterech podwójnych szaf rozdzielczych } \\
\text { (szerokość x głebokość x wysokość) }\end{array}$ & & & \\
- szafa +S1/+S2 i +S3/+S4 & {$[\mathrm{m}]$} & $1,4 \times 0,7 \times$ & $1,4 \times 0,7 \times 2,7$ \\
- szafa +S5/+S6 i +S7/+S8 & {$[\mathrm{m}]$} & 2,7 & $1,2 \times 0,9 \times 2,7$ \\
& & $1,2 \times 0,9 \times$ & \\
\hline Waga & {$[\mathrm{kg}]$} & 4000 & 4300 \\
\hline
\end{tabular}

Tabela 2. Dane techniczne zasobnika MITRAC Energy Saver [9]

\begin{tabular}{|l|c|c|c|c|}
\hline Zastosowanie & & LRV 2003 & LRV 2008 & DMU \\
\hline Pojemność energetyczna & {$[\mathrm{kWh}]$} & 1 & 1 & 1,17 \\
\hline Moc szczytowa & {$[\mathrm{kW}]$} & 300 & 300 & 100 \\
\hline Chłodzenie & & $\begin{array}{c}\text { Powietrzne wymu- } \\
\text { szone }\end{array}$ & $\begin{array}{c}\text { Powietrzne wymu- } \\
\text { szone }\end{array}$ & Powietrzne naturalne \\
\hline Waga & {$[\mathrm{kg}]$} & 477 & 400 & 466 \\
\hline Wymiary & {$[\mathrm{mm}]$} & $1900 \times 950 \times 455$ & $\begin{array}{c}1700 \times 680 \times 450 \\
\text { (częściowo 550) }\end{array}$ & $1800 \times 1500 \times 250$ \\
\hline Standardowa eksploatacja & & $\begin{array}{c}2 \text { bloki dla 30m } \\
\text { LRV } \\
2 \mathrm{kWh}, 600 \mathrm{~kW}\end{array}$ & $\begin{array}{c}2 \text { bloki dla 30m } \\
\text { LRV } \\
2 \mathrm{kWh}, 600 \mathrm{~kW}\end{array}$ & $\begin{array}{c}6 \text { bloków dla 4 pojazdów } \\
\text { AGC } \\
7 \mathrm{kWh}, 600 \mathrm{~kW}\end{array}$ \\
\hline
\end{tabular}

powoduje, że energia odzyskana musi być przesyłana od pojazdu do zasobnika. Prowadzi to do strat energii, które występują w przewodach zasilających. Szacuje się, że straty te mogą sięgać $15 \%$ [9] odzyskanej energii.

\section{Pojazdowe zasobniki energii}

Dzięki temu, że zasobnik znajduje się na pojeździe, eliminuje się starty związane $\mathrm{z}$ przesyłem energii. Energia, która odzyskiwana jest $\mathrm{w}$ trakcie hamowania elektrodynamicznego, magazynowana jest w zasobniku, a następnie wykorzystana przy najbliższym zapotrzebowaniu na nią. Najefektywniejsze działanie zasobnika można uzyskać w krótkodystansowych pojazdach komunikacji pasażerskiej tj. metro, tramwaje, trolejbusy czy kolej podmiejska. Wynika to z ich charakteru pracy: krótkie dystanse pomiędzy przystankami, częste hamowanie i przyspieszanie.

Od grudnia 2005 roku w Warszawie eksploatowany jest tramwaj $116 \mathrm{~N} \mathrm{z}$ akumulatorowym zasobnikiem energii o pojemności 80 Ah i napięciu znamionowym $600 \mathrm{~V}$, zbudowanym z 500 ogniw po $1,2 \mathrm{~V}$ każde. Całkowita masa zasobnika wynosi 2650 kg. Dzienny przebieg tramwaju wynosi ok. $280 \mathrm{~km}, \mathrm{w}$ tym $85 \mathrm{~km}$ na zasilaniu wyłącznie z zasobnika. Poważnym problemem jest w tym systemie zbyt krótka żywotność akumulatorów, która przy rozładowywaniu baterii ok. $21 \%$ określona została przez producenta na 13 tysięcy cykli. Wynika $\mathrm{z}$ tego, że baterie w zasobniku wystarczą na 3 do 4 lat eksploatacji, po czym będa wymagały wymiany [3]. Problem żywotności baterii rozwiązują superkondensatory, których liczba możliwych cykli w zależności od podawanych źródeł kształtuje się na poziomie od 500 tys. do 1500 tys. [6, 7]. Pojazdowy zasobnik na bazie superkondensatorów wykonała firma Bombardier [9]. MITRAC Energy Saver został opracowany z myślą o lekkich pojazdach szynowych (Light Rail Vehicles - LRV) oraz spalinowych zespołach trakcyjnych (Diesel Multiple Unit $D M U)$. Wybrane dane techniczne zostały przedstawione w tabeli 2.

Odzysk energii podczas hamowania producent określa na poziomie do $30 \%$. Zmagazynowana energia jest wykorzystywana podczas ruszania i przyspieszania pojazdu. Dzięki mniejszemu obciążeniu podstacji, występują mniejsze wahania prądów i napięć w sieci trakcyjnej (Rys. 2). 


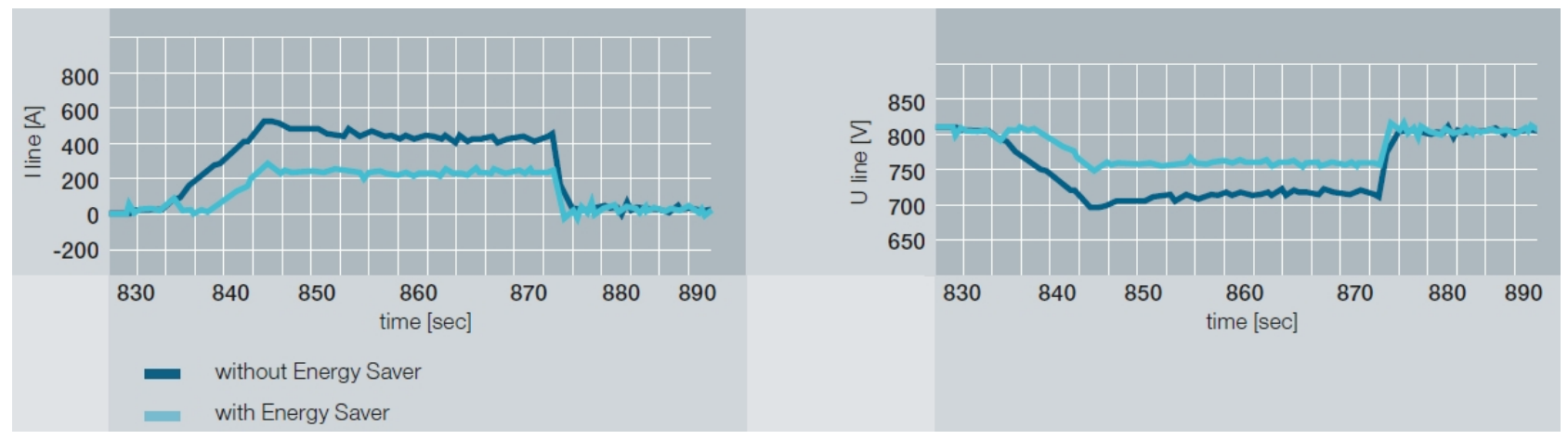

Rys.2. Przebiegi prądów i napięć w sieci trakcyjnej bez zasobnika i z zasobnikiem MITRAC Energy Saver [9]

Możliwe jest również wykorzystanie odzyskanej energii do poprawienia osiągów pojazdu, m.in. zwiększenia przyspieszenia (Rys. 3).

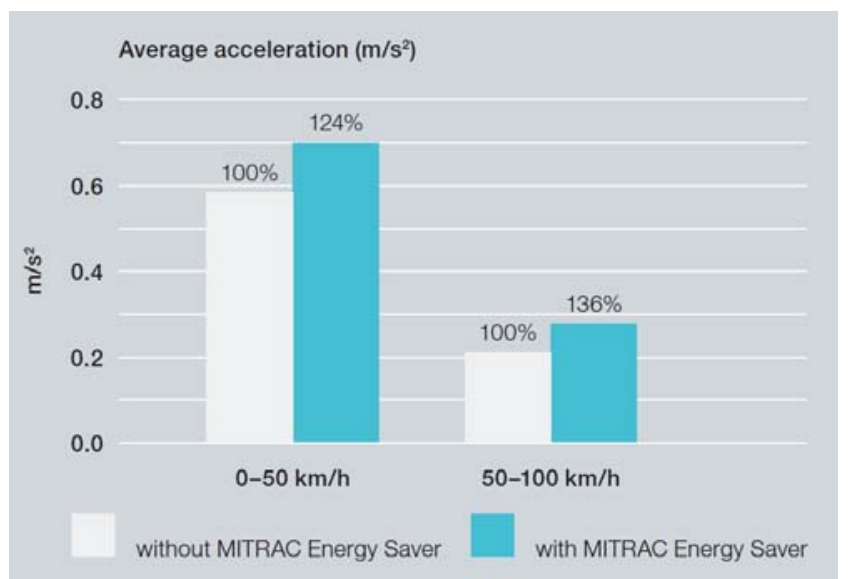

Rys..3. Wartości średniego przyspieszenia dla pojazdu DMU bez zasobnika i z zasobnikiem MITRAC Energy Saver [9]

Zaletą instalowania zasobnika na pojeździe jest to, że pojazdy te mogą przejechać pewien dystans bez zasilania z sieci trakcyjnej. Firma Bombardier podaje, że nowoczesne pojazdy LRV wyposażone w zasobnik MITRAC Energy Saver mogą przejechać dystans około $500 \mathrm{~m}$ wykorzystując wyłącznie energię z zasobnika [9].

Chcąc zastapić we wspomnianym wcześniej tramwaju $116 \mathrm{~N}$ zasobnik akumulatorowy superkondensatorowym należy obliczyć jego szacunkową pojemność według schematu (3-8) opisanego poniżej [2, 7]. W tym celu należy założyć następujące parametry systemu odzyskiwania energii: ilość możliwej do odzyskania energii, napięcie robocze oraz czas przejmowania energii. Na początku należy przyjąć założenie, że możliwe jest do odzyskania $25 \%$ energii pobranej przez pojazd podczas rozruchu i przyspieszania. Tramwaj posiada 4 silniki prądu stałego o mocy $55 \mathrm{~kW}$ każdy. Jego maksymalny prąd rozruchowy wynosi 2 x320 A przy napięciu znamionowym $600 \mathrm{~V}$. Średnie przyspieszenie $0,7 \mathrm{~m} / \mathrm{s}^{2}$ powoduje w czasie $\sim 12$ sekund rozpędzenie pojazdu do prędkości $\mathrm{v}=30 \mathrm{~km} / \mathrm{h}$ [3]. Energia potrzebna na rozruch i przyspieszenie pojazdu:

$$
E_{r}=2 \cdot I_{r} \cdot U_{n} \cdot t_{r}=1,28 \mathrm{kWh}
$$

gdzie: $E_{\mathrm{r}}$ - energia potrzebna na rozruch i przyspieszenie pojazdu, $I_{\mathrm{r}}-$ prąd rozruchowy, $\mathrm{U}_{\mathrm{n}}$ - napięcie nominalne, $\mathrm{t}_{\mathrm{r}}$ - czas trwania rozruchu $\mathrm{i}$ przyspieszania pojazdu.

Energia możliwa do odzyskania podczas hamowania:

$$
E_{o}=25 \% E_{r} \cong 0,32 \mathrm{kWh}
$$

Zakładając, że hamowanie odzyskowe odbywa się od prędkości $30 \mathrm{~km} / \mathrm{h}$ do $10 \mathrm{~km} / \mathrm{h}$ [10] ze stałym opóźnieniem $1,4 \mathrm{~m} / \mathrm{s}^{2}$, trwa ono około $? \mathrm{t}=4 \mathrm{~s}$. Dodatkowo należy uwzględnić stałą czasową pojedynczych superkondensatorów w modułach BMOD, która wynosi około 1s [2]. Wartościami, które również warunkują pracę zasobnika są: wartość maksymalna napięcia baterii superkondensatorów $U_{\text {MAX }}$ oraz minimalna $\mathrm{U}_{\mathrm{MIN}}$ do której bateria może być rozładowana. Zostały przyjęte wartości napięć $\mathrm{U}_{\mathrm{MAX}}=750 \mathrm{~V}$ oraz $\mathrm{U}_{\mathrm{MIN}}=$ $500 \mathrm{~V}$ [4]. Zatem różnica napięć ? U $=250 \mathrm{~V}$.

$$
\begin{gathered}
i_{M A X}=\frac{E_{o}}{U_{M I N} \cdot \Delta t}=576 \mathrm{~A} \\
i_{M I N}=\frac{E_{o}}{U_{M A X} \cdot \Delta t}=384 \mathrm{~A} \\
i_{S R}=\frac{i_{M A X}+i_{M I N}}{2}=480 \mathrm{~A} \\
C=\frac{i_{S R}}{\Delta U}(\Delta t+1)=9,6 \mathrm{~F}
\end{gathered}
$$

Łącząc szeregowo 280 superkondensatorów firmy Maxwell o pojemności $3000 \mathrm{~F}$ każdy i napięciu znamionowym $2,7 \mathrm{~V}$ otrzymamy moduł o dopuszczalnym napięciu $756 \mathrm{~V}$ i pojemności $10,71 \mathrm{~F}$. Waga takiego modułu będzie wynosiła $154 \mathrm{~kg}$. Trzeba mieć świadomość, że to nie jest gotowy zasobnik. Dołączając do modułu superkondensatorów układy wyrównywania napięć, przetwornicę dwukierunkową, aparaturę łączeniową i zabezpieczającą oraz układ sterowania, otrzyma się kompletny pojazdowy zasobnik energii elektrycznej. 


\section{Podsumowanie}

Systemy zasobnikowe, dzięki którym istnieje możliwość magazynowania odzyskanej energii, moga mieć zastosowanie we wszelkich pojazdach elektrycznych. Jednak wiele kwestii dotyczących sterownia przepływem energii ciagle pozostaje otwartych. Nowe technologie, takie jak superkondensatory, daja podstawy do ciagkego rozwoju i modernizacji systemów zasobnikowych. Krótkie czasy ładowania i rozładowania, duża liczba cykli bez utraty właściwości sprawiają, że superkondensatory są konkurencyjne wobec obecnych akumulatorów, pomimo, że obecnie ustępują im pod względem gęstości energii. Pojazdowe zasobniki energii pozwalają wyeliminować straty związane z przesyłem odzyskanej energii do podstacji. Zmagazynowana energia wykorzystywana jest podczas rozruchu co zmniejsza spadki napięć i pobór prądu z sieci trakcyjnej. Dzięki dodatkowej energii poprawiają się osiagi pojazdów oraz możliwy jest przejazd przez odcinki niezelektryfikowane.

* Stuchacz studiów doktoranckich na Wydziale Elektrotechniki, Elektroniki, Informatykii Automatyki Politechniki Łódzkiej. Stypendysta projektu „Innowacyjna dydaktyka bez ograniczeń - zintegrowany rozwój Politechniki Łódzkiej-zarzadzanie uczelnia, nowoczesna oferta edukacyjnai wzmacnianie zdolności do zatrudniania, także osób niepetnosprawnych" wspótfinansowanego przez Unię Europejska w ramach Europejskiego Funduszu Społecznego.

\section{Literatura:}

[1] Olszowiec P.: Rozwój zasobników energii elektrycznej wielkiej mocy: Superkondensatory i akumulatory ratuja systemy elektroenergetyczne. Energia Gigawat, styczeń 2009.

[2] Juda Z.: Zastosowanie Superkondensatorów w układzie odzysku energii pojazdu z napędem elektrycznym. Czasopismo Techniczne M, Wydawnictwo Politechniki Krakowskiej 6-M/2008.

[3] Gasiewski M.: Tramwaj z akumulatorowym zasobnikiem energii - wyniki eksploatacji. Technika Transportu Szynowego 1-2/2007.

[4] Giziński P.: Kondensatorowy zasobnik energii do pojazdów trakcji elektrycznej. Technika Transportu Szynowego 1-2/2007.

[5] Czucha J., Karwowski K., Mizan M., Pazdro P.: Efektywność odzysku energii hamowania elektrodynamicznego $w$ komunikacji miejskiej. Przeglad Elektrotechniczny R. 80 nr 10/2004 1016-1019.

[6] Pigoń K., Ruziewicz Z.: Chemia fizyczna, Wydanie drugie. PWN Warszawa 1981.

[7] www.maxwell.com/ultracapacitors/

[8] www.siemens.com/mobility

[9] www.bombardier.com/en/transportation/sustainability /technology

[10] Górowski M. www.transportszynowy.pl 